\title{
Subependymal Giant Cell Astrocytoma
}

National Cancer Institute

\section{Source}

National Cancer Institute. Subependymal Giant Cell Astrocytoma. NCI Thesaurus. Code C3696.

A benign, slowly growing tumor (WHO grade I) typically arising in the wall of the lateral ventricles and composed of large ganglioid astrocytes. It is the most common CNS neoplasm in patients with tuberous sclerosis complex and typically occurs during the first two decades of life. (WHO) 